\title{
Response of Micropropagated Apple Trees to Field Establishment Procedures
}

\author{
Richard H. Zimmerman \\ Fruit Laboratory, Agricultural Research Service, U.S. Department of \\ Agriculture, Beltsville, MD 20705
}

Additional index words. Malus domestica, in vitro culture, micropropagation, cultural practices, vegetative growth, flowering, fruiting

\begin{abstract}
Growth, flowering, and fruiting of micropropagated 'Jonathan' apple trees (Malus domestica Borkh.) transferred in Spring 1983 to the field from either a nursery, cold storage, or greenhouse were compared. First-year shoot and trunk growth was greatest for trees transplanted from the nursery and least for trees that were held in the greenhouse before being transferred to the field. Trees pruned low $(35 \mathrm{~cm})$ at planting time had more terminal shoot growth and less trunk cross-sectional area after the first growing season than those pruned high $(90 \mathrm{~cm})$. The effect of preplanting cultural practices on vegetative growth diminished in the 2nd year and disappeared by the end of the 3rd year in the orchard. Flowering began in 1985 and was only slightly affected by preplanting cultural practices and pruning treatments. Fruiting was not affected by the treatments.
\end{abstract}

Micropropagation can be used to produce self-rooted apple trees with relative ease. Long-term field evaluations of vegetative growth, flowering, and fruiting characteristics are needed before such trees can be recommended for orchard planting. Such experiments to evaluate these characteristics have been established (Rosati and Gaggioli, 1987; Webster et al., 1985; Zimmerman and Miller, 1985; Zimmerman and Steffens, 1989); however, a variety of cultural treatments were used in producing the plants before being planted in the orchard. Moreover, at that time, the micropropagated trees differed greatly in size among experiments and in relation to the budded trees used for controls. A comparison of the various reports makes it clear that these early cultural practices can strongly influence later performance of the trees (Zimmerman, 1986). The experiment reported here compared the effect of several cultural practices and two pruning heights at planting on subsequent vegetative growth, flowering, and fruiting of micropropagated 'Jonathan' apple trees under field conditions and was part of a program to determine the most effective method for field establishment of micropropagated apple trees.

'Jonathan' apple trees were micropropagated in 1982 using methods described by Zimmerman and Broome (1981). Following acclimatization, the plants were grown in the greenhouse for varying periods. After 3

Received for publication 17 Apr. 1991. The cost of publishing this paper was defrayed in part by the payment of page charges. Under postal regulations, this paper therefore must be hereby marked advertisement solely to indicate this fact. months there, plants in one group [nursery (N)] were moved to a nursery 6 July when they were $\approx 50 \mathrm{~cm}$ tall and actively growing. Plants in a second group [greenhouse + cold (GC)] remained in the greenhouse for 4.5 months, until 15 Oct., when they were moved outdoors for hardening and then were moved to a common storage on 16 Nov. for the winter. Plants in a third group [greenhouse (G)] remained in the greenhouse all winter, where they were maintained on long days with a 2-h light break in the middle of the night. Plants in groups $\mathrm{GC}$ and $\mathrm{G}$ were grown in black plastic containers $\approx 10 \times 10 \times 35$ $\mathrm{cm}$ until planted in the field. Trees from all three groups were planted in an orchard 22 Apr. 1983, at a spacing of $4.3 \mathrm{~m}$ in row $x$ $4.9 \mathrm{~m}$ between rows. Immediately after planting, all lateral shoots were removed to make the trees more uniform, since all $\mathrm{N}$ trees had laterals and almost none of the others did. Half the trees in each group were headed low (at $35 \mathrm{~cm}$ ) and the other half high (at $90 \mathrm{~cm}$ ). Since the $\mathrm{N}$ trees were shorter than $90 \mathrm{~cm}$, they were headed at $60 \mathrm{~cm}$ at planting and at $90 \mathrm{~cm}$ after the first flush of growth in early June. Four-tree plots were used and treatments were replicated four times, giving 16 trees per treatment arranged in a randomized complete-block design. Data were collected annually on trunk diameter 30 $\mathrm{cm}$ above the ground, terminal and total shoot growth, height, and spread in and across rows, flowering intensity, and fruit yield. Data were analyzed using the General Linear Model (GLM) procedure of SAS (SAS Institute, 1987) and orthogonal contrasts were used to compare treatments.

During the first growing season (1983), trees pruned low made significantly more terminal shoot growth and had significantly less trunk cross-sectional area (TCSA) than trees pruned high (Table 1). Trees from the nursery $(\mathrm{N})$ made significantly more shoot growth than those from the other two groups (Table 1). Nursery trees pruned high produced more shoot growth and had a larger TCSA than trees in the other two groups (Table 1).

After an additional year of growth (1984), differences among treatments were less. Trees pruned low still made significantly longer terminal shoot growth but had less TCSA (Table 1). Nursery trees generally had more shoot growth than trees in the other two groups, but otherwise did not differ from the $\mathrm{GC}$ trees. Both $\mathrm{N}$ and $\mathrm{GC}$ trees had greater spread and TCSA than $G$ trees. Terminal shoots were longer on $\mathrm{G}$ than on GC trees. Mean shoot growth was longer on $\mathrm{N}$ trees pruned high at planting than on the similarly treated GC and $G$ trees. Essentially, vegetative growth among treatments was similar in the third and later growing seasons.

Flowering began in 1985. It was not affected by initial pruning height except in 1986, when trees pruned low had more flowers (Table 2). The $\mathrm{N}$ trees had more flowers than GC trees in 1985 and more than the $\mathrm{G}$ trees in 1985-87; GC trees had more flowers than the $\mathrm{G}$ trees in 1986-87. The $\mathrm{N}$ trees pruned high had significantly more flowering only in 1985 and 1986 than the GC + G trees pruned high. Flowering intensity was lower in 1988 and 1989 and there were no differences among treatments.

Fruit yields were very low and did not differ among treatments. The mean annual per-tree yields for 1985-89 were 0.2, 10.9, $6.1,8.8$, and $10.9 \mathrm{~kg}$. The low yields resulted in a cumulative yield efficiency of 0.27 kg.cm- ${ }^{2}$ TCSA at the end of the experiment.

The greater growth made in the first year in the orchard by the micropropagated trees transplanted from the nursery is probably attributable to the more extensive root system that these trees had at planting time. After 2 years in the orchard, the advantage of the nursery-grown trees had disappeared and tree size differences resulting from the initial treatments no longer existed.

Initial flowering was somewhat more intense on the larger trees, but this was not reflected in any higher fruit yield. The 'Jonathan' trees in this experiment took at least 1 year longer from time of micropropagation until flowering than micropropagated 'Jonathan' trees in another experiment located nearby that were planted directly in the orchard in June while the trees were $\approx 50 \mathrm{~cm}$ tall and actively growing (R.H.Z., unpublished data).

One possible explanation for the light crops of 'Jonathan' may be poor pollination. 'Jonathan' and 'Rome' are the last cultivars to bloom in the orchards at Beltsville. Micropropagated trees of both cultivars have had 
Table 1. Effect of source of plants and pruning height at planting on growth of micropropagated 'Jonathan' apples during the first 2 years (1983 and 1984) in the orchard.

\begin{tabular}{|c|c|c|c|c|c|c|c|c|c|c|c|c|}
\hline \multirow[b]{3}{*}{ Variable } & \multirow{2}{*}{\multicolumn{2}{|c|}{$\begin{array}{l}\text { Nursery } \\
\text { (N) }\end{array}$}} & \multirow{2}{*}{\multicolumn{2}{|c|}{$\begin{array}{l}\text { Greenhouse }+ \\
\text { cold }(\mathrm{GC})\end{array}$}} & \multirow{2}{*}{\multicolumn{2}{|c|}{$\begin{array}{c}\text { Greenhouse } \\
\text { (G) }\end{array}$}} & \multirow[b]{3}{*}{$\mathbf{F}$} & \multicolumn{5}{|c|}{ Contrasts } \\
\hline & & & & & & & & \multirow{2}{*}{$\begin{array}{l}\text { Low } \\
\text { vs. } \\
\text { high }\end{array}$} & \multirow{2}{*}{$\begin{array}{c}\text { N } \\
\text { vs. } \\
\text { GC }\end{array}$} & \multirow{2}{*}{$\begin{array}{c}\mathrm{N} \\
\text { vs. } \\
\mathrm{G}\end{array}$} & \multirow{2}{*}{$\begin{array}{c}\mathrm{GC} \\
\text { vs. } \\
\mathrm{G}\end{array}$} & \multirow{2}{*}{$\begin{array}{c}\mathrm{N}-\mathrm{H} \\
\text { vs. } \\
\mathrm{GC}-\mathrm{H}+ \\
\mathrm{G}-\mathrm{H}\end{array}$} \\
\hline & Low $^{z}$ & Highy & $\operatorname{Low}^{z}$ & $\mathrm{High}^{2}$ & Low $^{2}$ & High $^{2}$ & & & & & & \\
\hline \multicolumn{13}{|c|}{1983} \\
\hline \multicolumn{13}{|l|}{ Terminal shoot } \\
\hline length $(\mathrm{cm})^{x}$ & 111 & 83 & 86 & 61 & 83 & 63 & $* * *$ & $* * *$ & $* * *$ & $* * *$ & NS & $* * *$ \\
\hline Total shoot growth $(\mathrm{m})^{\mathbf{x}}$ & 9.6 & 8.4 & 7.7 & 7.9 & 3.0 & 2.5 & $* * *$ & NS & $*$ & $* * *$ & $* * *$ & $* * *$ \\
\hline TCSA initial $\left(\mathrm{cm}^{2}\right)$ & 0.39 & 0.44 & 0.36 & 0.36 & 0.55 & 0.50 & $* * *$ & NS & NS & $* * *$ & $* * *$ & NS \\
\hline TCSA final $\left(\mathrm{cm}^{2}\right)^{x}$ & 2.0 & 2.2 & 1.6 & 2.2 & 1.0 & 1.4 & $* * *$ & $* * *$ & NS & $* * *$ & $* * *$ & $* *$ \\
\hline \multicolumn{13}{|c|}{1984} \\
\hline Spread in row $(m)^{x}$ & 1.5 & 1.4 & 1.4 & 1.5 & 1.4 & 1.3 & $*$ & NS & NS & $* *$ & $* *$ & NS \\
\hline Spread across row (m) & 1.5 & 1.5 & 1.4 & 1.5 & 1.4 & 1.3 & $*$ & NS & NS & ** & $* *$ & NS \\
\hline Terminal shoot length $(\mathrm{cm})$ & 126 & 122 & 120 & 113 & 133 & 118 & ** & ** & $*$ & NS & $* *$ & NS \\
\hline Mean shoot length $(\mathrm{cm})$ & 99 & 106 & 95 & 98 & 99 & 94 & $* *$ & NS & ** & $* *$ & NS & $* * *$ \\
\hline $\operatorname{TCSA}\left(\mathrm{cm}^{2}\right)^{x}$ & 9.5 & 9.0 & 7.7 & 9.5 & 6.9 & 7.9 & $* * *$ & $*$ & NS & $* * *$ & $*$ & NS \\
\hline
\end{tabular}

Trees pruned at time of planting low $(35 \mathrm{~cm})$ or high $(90 \mathrm{~cm})$.

yTrees pruned at height of $60 \mathrm{~cm}$ at time of planting and again at $90 \mathrm{~cm}$ in early June 1983.

'Means adjusted for trunk cross-sectional area at time of planting because of significant covariate.

Ns. ******Nonsignificant or significant at $P=0.05,0.01$, or 0.001 , respectively.

Table 2. Effect of source of plants and pruning height at planting on flowering of micropropagated 'Jonathan' apples during years 3 , 4, and 5 in the orchard.

\begin{tabular}{|c|c|c|c|c|c|c|c|c|c|c|c|c|}
\hline \multirow[b]{3}{*}{ Year } & \multirow{2}{*}{\multicolumn{2}{|c|}{$\begin{array}{l}\text { Nursery } \\
(\mathrm{N})\end{array}$}} & \multirow{2}{*}{\multicolumn{2}{|c|}{$\begin{array}{c}\text { Greenhouse }+ \\
\text { cold (GC) }\end{array}$}} & \multirow{2}{*}{\multicolumn{2}{|c|}{$\begin{array}{c}\text { Greenhouse } \\
\text { (G) }\end{array}$}} & \multirow[b]{3}{*}{$\mathrm{F}$} & \multicolumn{5}{|c|}{ Contrasts } \\
\hline & & & & & & & & \multirow{2}{*}{$\begin{array}{l}\text { Low } \\
\text { vs. } \\
\text { high }\end{array}$} & \multirow{2}{*}{$\begin{array}{c}\mathrm{N} \\
\mathrm{vs} . \\
\mathrm{GC}\end{array}$} & \multirow{2}{*}{$\begin{array}{c}\text { N } \\
\text { vs. } \\
\text { G }\end{array}$} & \multirow{2}{*}{$\begin{array}{c}\mathrm{GC} \\
\text { vs. } \\
\mathrm{G}\end{array}$} & \multirow{2}{*}{$\begin{array}{c}\mathrm{N}-\mathrm{H} \\
\text { vs. } \\
\mathrm{GC}-\mathrm{H}+ \\
\mathrm{G}-\mathrm{H}\end{array}$} \\
\hline & $\overline{\text { Low }^{2}}$ & High $^{y}$ & Low $^{z}$ & High $^{2}$ & Low $^{z}$ & High $^{2}$ & & & & & & \\
\hline 1985 & $1.9^{x}$ & $\overline{2.1}$ & 1.6 & $\overline{1.6}$ & 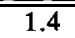 & 1.3 & NS & NS & * & ** & NS & *** \\
\hline 1986 & 6.9 & 7.1 & 7.4 & 6.9 & 7.1 & 5.7 & $* * *$ & $* *$ & NS & $*$ & $*$ & $*$ \\
\hline 1987 & 8.0 & 7.9 & 8.3 & 8.3 & 7.6 & 7.1 & $*$ & NS & NS & * & $* *$ & NS \\
\hline
\end{tabular}

Trees pruned at time of planting low $(35 \mathrm{~cm})$ or high $(90 \mathrm{~cm})$.

Yrees pruned at height of $60 \mathrm{~cm}$ at time of planting and again at $90 \mathrm{~cm}$ in early June 1983 .

${ }^{\times}$Rating scale for no. flower clusters: $1=$ none; $2=1-5 ; 3=6-10 ; 4=11-25 ; 5=26-50 ; 6=51-100 ; 7=101-250 ; 8=251-500 ; 9=>500$.

NS. *. **.***Nonsignificant or significant at $P=0.05,0.01$, or 0.001 , respectively.

lower yields than anticipated, as have budded trees of 'Rome', in all experiments conducted at this location. Further testing at other sites is needed to determine whether poor fruit set and low yields are a result of micropropagation per se, or result from interactions among propagation method, cultivar, and site.

These results indicate that growth of trees in the nursery or greenhouse and differential pruning immediately after planting had little effect on tree size, precocity, or productivity despite initial differences in growth. Cultural practices that avoid pruning and disturbance of the root system might prove to be desirable in producing precocious flowering and fruiting in micropropagated trees (Zimmerman and Steffens, 1989).

\section{Literature Cited}

Rosati, P. and D. Gaggioli. 1987. Field performance of micropropagated peach rootstocks and scion cultivars of cherry and apple. Acta Hort. 212:379-390.

SAS Institute, Inc. 1987. SAS/STAT guide for personal computers, version 6 (ed.). SAS Institute, Inc., Cary, N.C.

Webster, A.D., V.H. Gehl, J.E. Jackson, and O.P. Jones. 1985. The orchard establishment, growth and precocity of four micropropagated apple scion cultivars. J. Hort. Sci. 60:169-180.

Zimmerman, R.H. 1986. Propagation of fruit, nut, and vegetable crops-overview, p. 183-200. In: R.H. Zimmerman, R.J. Griesbach, F.A. Hammerschlag, and R.H. Lawson (eds.). Tissue culture as a plant production system for horticultural crops. Martinus Nijhoff, Dordrecht, Netherlands.

Zimmerman, R.H. and O.C. Broome. 1981. Phloroglucinol and in vitro rooting of apple cultivar cuttings. J. Amer. Soc. Hort. Sci. 106:648652.

Zimmerman, R.H. and S.S. Miller. 1985. Field growth of tissue-cultured compared to budded apple trees. HortScience 20:584. (Abstr.).

Zimmerman, R.H. and G.L. Steffens. 1989. Management of self-rooted tissue-cultured apple trees: I. Orchard establishment and early growth. Acta Hort. 239:117-120. 